\title{
The Social Symbolism of Biafra Protest Songs in South- Eastern Nigeria
}

\author{
Scholastica Ngozi Atata ${ }^{1}$ \\ Ayokunle Olumuyiwa Omobowale ${ }^{2}$
}

\author{
Department of Communication and General Studies ${ }^{1}$ \\ Federal University of Agriculture, Abeokuta, Nigeria \\ Department of Sociology ${ }^{2}$ \\ University of Ibadan, Ibadan, Nigeria
}

DOI:10.36108/NJSA/8102/61(0110)

\begin{abstract}
Protests are an essential element of democratisation process and a significant factor in the social struggle and commitment to a cause. Protests are staged in different forms, either, with placards or songs to portray socio-political grievance. This study explains the symbolism of Biafra protest songs in South-Eastern Nigeria. Protest songs are symbols that contextualise intent of a social struggle. The protest songs depict cultural and group ideology which fosters the Igbo identity cohesion in the Biafra struggle. These protest songs indicate shared patterns of behaviour and interaction, cognitive constructs and understanding that create unique symbolism of Biafra among the Igbo people in Nigeria. This paper argues that Biafra protest songs are a non-material culture that contextualises the meanings attached to Biafra in achieving identitycapital, identity-cohesion, struggle sustenance and commitment during protests.
\end{abstract}

Keywords: Biafra, protest songs, the Igbo, identity capital, South-East Nigeria

\section{Introduction}

The Biafra agitation remains a significant movement in the history of Nigeria. The attempt at making Biafra a country resulted in the Nigerian Civil War of 1967-1970, and the contemporary calls through the activities of the Movement for the Actualization of the Sovereign State of Biafra (MASSOB) (as from the year 2000). Lately, the Indigenous People of Biafra (IPOB), continues to agitate against Igbo marginalisation with an ultimate aim for self-determination through sovereignty (Onwuegbuchulam and Mtshali, 2017; Agbiboa, 2013). Notably, protest songs are significant features of Biafra agitation. Social movements adopt protests as a potent social mechanism, with a goal to raise consciousness against and mitigate the effects of socio-political prejudice, maladministration, and all acts of marginalisation and social injustice in governance and call for positive change (van Stekelenburg and Klandermans, 2010; Dalton, Sickle and Weldon, 2010). Lately, the potency of protests at bringing about change in government policies and strategies and change of government has been acknowledged, especially with the phenomenal Arab Spring in the Middle East (Ghanem, 2016). Protest songs form a significant feature of mass actions that are aimed at gingering actors' symbolic expression 
of resistance, and at the same time engender popular consciousness and cohesion among protesters (Brooks, 2014; Payerhin, 2012). Protest songs act as a social mechanism to portray the objectives of aggrieved group(s) and present a symbolic connotation (Cooke and Doornbos, 1982). This study, therefore, examines the social symbolism of Biafra protest songs in South-Eastern Nigeria.

The symbolic context of the protest songs explain the motives and demands of protesters (Akinwumi, 2005). Protest songs are major tools of protesters' cohesion that facilitate in-group bonding capital amidst violent circumstances. The engendering of group cohesion through melody remains a critical subject for epistemic scrutiny especially, on how song symbols advance group bonding. Gunner (1986) opines that songs often present cultural symbols, which portray the identity and unity of a group. Aside from the spontaneous lyrics created to entertain and motivate the populace, protest songs mainly originate among social groups, especially in the context of agitation. Protest songs are constructed to drive symbolic meanings and messages to the listeners and encourage the protesters in the face of activism.

Biafra protest is phenomenal, as many Igbo social movement groups propagate the Biafran cause and ideology using different protest songs. The songs thus create embedded social meanings among Biafran activists and supporters during protests. As mentioned earlier, the contemporary use of Biafran protest songs is linked to Nigeria Civil War (Achebe, 2012; Onuoha, 2011; Okonta and Meagher, 2009; Diamond, 2007; Effiong, 2000; Agu, 1991; Nwachukwu-Agabada, 1996; Achuzia, 1986) where songs were adopted to energize and encourage Biafran soldiers. The resurgence of Biafra activism from about the year 2000, has witnessed a resurgence of Biafra protest songs among the pro-Biafra Igbo. This agitation has not been without constant confrontations between the different pro-Biafra social movement groups such as the MASSOB and IPOB and other less popular groups such as the Biafra Government in Exile (BGIE) formed in 2004, Biafra Liberation Movement (BLM) formed in 2003, the Biafra Nigeria World (BNW) formed 2003, Coalition of Biafra Liberation Groups (COBLIG) formed in 2002 and the Biafra Independence Movement (BIM) (Duruji, 2009; Omeje, 2005; Adekson, 2004). The MASSOB was the first social movement to re-introduce Biafra protests, in the year 1999 and subsequently, the IPOB continues to project Biafra cause with protest with the aid of protest songs. Although the Nigerian state deems Biafra activism as illegal, the Biafran protest remains active still (Ibeanu, Orji and Iwuamadi, 2016; Okonta, 2012). Despite the illegality of Biafra protest and the activities of the Biafran activism it is important to note that, since the year 2000, Biafra protest have gained phenomenal social recognition with the use of a variety of Biafran songs especially among the pro-Biafra agitators South-eastern Nigeria.

The Biafra protest and popularity of the protest songs among Biafra activists have resulted in confrontations between Biafran activists and the coercive forces of the Nigerian state (Afeno, 2014). According to Ujumadu 
(2013), Obe (2013), Uzoaru (2015) and Nzeagwu, Ogugbuaja, Tsokar and Ilozue (2015) clashes between Nigerian Police and Biafra protesters in parts of south-east on June 8, 2013, August 8, 2013 on September 30, 2013 and on December 27, 2013, May, 30 and December 3, 2015, narrate increasing contests for Biafra through protests and use of songs to express the embedded social symbols of the Biafran ideology (Ibekwe, 2016; Ugwuanyi, 2016; Agbambu and Oruya, 2015; Ihejirika, 2015). This paper, therefore, examines the protest songs chanted in the Igbo language, which express the in-group identity, struggle and commitment to 'Biafra' in South-Eastern Nigeria.

The authors observe that Biafra protest songs originate among the Igbo, and Biafrans activists predominantly use these songs in projecting the Biafra cause. Whereas some of the protest songs call for secession, others are motivational in lyrics and seek to bolster protesters bonding, comfort and hope for success. The protest songs utilise rendition and cultural, rhetorical resources and gains to motivate, sustain, and encourage social cohesion, identity and patriotic commitment in the Biafran cause in South-Eastern Nigeria and among all Igbo irrespective of the place of domicile. Biafra protest songs constitute a symbolic collective performance in the propagation of Biafra identity commitment and struggle among the Igbo. Qualitative data were collected during the observation of Biafra protests in Aba, Abia State in November 2015 and January 2016 and from jingles on Radio Biafra FM 102.1 MHz. The eight protest songs that were popularly rendered during these protests were subjected to contextual analysis. The 8 protest songs were Ebe ka unu si? Biafra...; (Where are you from? Biafra...) I'kwere na Biafra, Biafra, Biafra? (Do you believe in Biafra, Biafra, Biafra?...); Ala nna anyi, Biafra...(Our Fatherland Biafra...); Nzogbu nzogbu...(Trample to death any obstruction...); Iwe iwe, iwe...Biafra (Anger, Anger Anger...Biafra); Owe gi mgbe ike madu ga akwusi Biafra...(There will be no time when human power can stop Biafra...); Biafra ka $m$ ga eso...(I will follow Biafra...); Anyi agagi ekwe ma anyi ewegi Biafra...(We will not agree if we do not have Biafra...).

\section{Theoretical Framework: Symbolic Interactionism}

This research adopted the theory of symbolic interactionism. Symbolic interactionism theory opines that people act in accordance to meanings attached to symbols that come in form actions. Actions and objects within an interacting community are all symbols to which meanings are attached, and the meanings attached would inform the course of action to be taken (Ritzer, 2012; Carter and Fuller, 2015). Symbolic interactionism explains the meaning of actions and how people interpret actions in specific interactions over space and time in a society. In Nigeria, the Biafra context remains a remarkable part of Nigeria's history, which is embedded with deep meanings drawn from the experiences of the pogrom of 1966 and 1967, the Nigerian Civil War and assumptions of Igbo marginalisation. Protest songs also convey the contemporary Biafra symbolism. This study, therefore, uses the symbolism 
theory to explain the meanings attached to the Biafra phenomenon and how these meanings are expressed through protest songs.

Herbert Blumer first used symbolic interactionism and it was subsequently expanded by George Mead and Erving Goffman (Fine, 1993; Bruce and Yearly, 2006; Ritzer, 2012; Carter and Fuller, 2015). Symbolic interactionism derives its name from the dual emphases on symbolism and interaction. Symbolism focuses on the meanings attached to symbolic social actions that are attributed to the social actors, while the interaction explains the how the interactions shape social actions and vice versa, and how all these interactions lead to the social construction of the self (Fine, 1993; Bruce and Yearley, 2006). Symbolic interactionism paradigm explains the meaning people attach to actions in their everyday life. This theory is of the taken-for-granted everyday epistemological perspective. Actors create their worlds through the meanings they construct from everyday interactions. These meanings are symbolic and are conveyed by language to give deep interpretive essence.

Biafra protest songs convey deep symbolic meanings. They convey the meanings of Biafra identity, struggle and commitment. Biafra protest songs symbolise the resolve to achieve Biafra and make Biafra nation a reality. This will be achieved through the commitment of individual believers in the ideals of Biafra. The meanings attached to the trio of Biafra identity, struggle and commitment emphasise actor's construction of the Biafra self, - a testimonial of Biafra nationalism, especially among the Igbo of Nigeria and in the Diaspora.

\section{Protest Song as Identity}

Identity explicitly expresses the categorisation of individuals as in-group or/and out-group (Jenkins, 2004). Studies have shown that people identify with the in-group especially in times of protests (see for example Van Stekelenburg and Klandermans, 2010; Stets and Burke, 2000; McNanara, 1997; Ashforth and Mael, 1989). This is an affirmation of the significance of cohesive identity as a factor that enhances group participation in protest as an overt expression of identity. Most importantly, the categorisation and classification of individuals in groups influence the commitment individuals have to the identity of the ingroup. The commitment is embedded in how the people overtly express their determination in achieving set goals. Stets and Burke (2003) argue that the number of people to whom an individual is connected to, through having a particular identity influences level of the commitment to the identity projected. This somewhat explains the use of songs to connect formidable and committed identity cohesion during Biafra protests.

Biafra protest songs of identity express a contextualised sense of Biafraness, emphasising Igbo nationalism in Biafra greatness. The songs present the willingness to project Biafra identity and nationalism as the preferred national identity. The songs construct and announce Biafra (Ukiwo, 2009; Hawley, 2008; Simola, 2000; Agu, 1991; Ike, 1999; NwachukwuAgbada, 1996). One of such songs goes thus: 
Ebe ka unu si?

Chorus: Biafra

Ebe ka unu si

Chorus: Biafra

Umunna ebe ka unu si

Chorus: Bi-a-fra
Where are you from?

Biafra

Where are you from

Biafra

Brethrens where are you from

Bi-a-fra

Ebe ka nu si promotes Biafra identity. It rhetorically asks: 'where are you from?...'; and the protesters reply Biafra! The song is a projection of Biafra identity and subtle rejection of the Nigerian identity. Agu (1991) and Nwachukwu-Agbada, (1996) earlier describe this song as a war song of identity and allegiance. Indeed Ebe ka unu si... militantly emphasises Biafra identity with a possibility of re-enacting a 'war' process to achieve it. Also, another song expresses identification with and faith in Biafra:

Ikwere na Biafra, Biafra, Biafra? Do you believe in Biafra,

Biafra, Biafra?

Ikwere na Biafra

Do you believe in Biafra

Bia we lere m aka gi elu

Come and raise your hand up

Eweliwo m akam elu

I have risen my hand up

Ekwerem na Biafra

I believe in Biafra

This song presents a call to support the Biafra cause. It is a protest song that calls on Igbo people to openly identify with Biafra; thus showing a sense of belongingness. The identification with Biafra is not supposed to be covert. The song enjoins protesters to openly identify with Biafra by raising their hands in affirmation of Biafra identity. Again, the protesters sing that Biafra is the Igbo fatherland that cannot be 'annexed' by Nigeria. The song says:
Ala nna anyi, Biafra
Our fatherland, Biafra
Nigiria apughi I nara anyi ya
Nigeria will not take our land from us
Si n'uwa
Even on earth
Si n'uwa ruo n' eluigwe
Even on Earth and in heaven

These protest songs illustrate the sense of Biafra as a social identity in the propagation of the campaign for self-determination. The songs have a precise identity function, to draw Biafra supporters into a movement by identifying with the Biafra in-group to achieve the Biafra cause. The songs draw on the internalised Biafra motivation value call on the Igbo to openly identify with Biafra as 'national' identity; away from the Nigerian identity. Biafra protest songs symbolically transform protesters from passive activists into active participants in the Biafra cause, especially with the internalisation of Biafra as the fatherland. These identity protest songs link identity construction with social cohesion as illustrated in the first song above-ebe ka unu si, Biafra. The songs prop and strengthen Biafra identity among the protesters and the larger segment of the Igbo, and somewhat super-impose Biafra identity as the preferred Igbo identity in the course of nationhood. 


\section{The Struggle Songs}

The enthusiasm about the Biafra cause propagates Igbo consciousness in support of the Biafra struggle. Struggle songs project the willingness and spirit of cohesion to achieve a common protest goal (Ebeogu, 1992; Ezeigbo and Gunner, 1991). Struggle protest songs ginger the consciousness to participate in Biafra struggle, despite the likelihood of confrontation with the coercive forces of the state and possible casualty. Through songs, protesters symbolically assume the strength they do not physically possess against the State. For example, protesters sing:

Nzogbu nzogbu Trample to death any obstruction (2 times),

Enyi mba enyi With the strength of an elephant

Nzogbu nzogbu Trample to death any obstruction (2 times)

Enyi mba enyi With the strength of an Elephant

Nzongbo, nzogbu is a traditional Igbo song, usually rendered while fighting against an enemy (Omeje, 2005; Ebeogu, 1992; Agu, 1991). The song describes the community strength like the strength of an elephant that crushes all obstacles on its way. It symbolically constructs community bonding and unity against a common enemy as the elephant's strength through which victory is assured. Hence, the Biafra cause is the goal that is prosecuted with the 'vanquishing' strength of a united people with the strength of a trampling elephant. Hence, the songs motivate and propel armless protesters against fully armed security forces of the State, under the assumption of victory someday. According to Omeje (2005), this song shows bravery and willingness to fight for Biafra amidst violence.

The next protest song further displays the vigour and anger to fight for Biafra:

Iwe iwe, iwe

Iwe na ewe anyi,

si ha ye anyi Biafra,

iwe

Si ha ye anyi Biafra, iwe
Anger, Anger, Anger

We are angry,

tell them to give us Biafra

Anger

Tell them to give us Biafra, We are angry

The song demonstrates protesters' anger and determination to have Biafra at all costs. The protesters demand, si ha ye anyi Biafra: they should give us Biafra. This is a subtle acceptance that having Biafra by armed conflict once failed. Biafra concession by negotiation may not readily be achievable, but the song yet indicates that the people concerned are angry and demand Biafra at all costs. The Federal Government of Nigeria views the call for Biafra as treasonable. Such legal-rational disposition alienates the Biafra cause, its adherents and protesters. This explains the reason why the coercive forces of the state are usually deployed against the Biafra agitation.

Nevertheless, the protest songs above present are people who would not allow their agitation to be suppressed. By expressing anger through songs, 
protesters express their commitment to the Biafra struggle. Hence, they declare that the powers of man cannot stop Biafra:

Owe gi mgbe ike madu ga

akwusi Biafra

Nna nuru olu anyi

Owe gi mgbe ike madu ga

akwusi Biafra

Olisa bini igwe bia nuru olu anyi
There will be no time when human powers will stop Biafra (twice)

God hears our voice

There will no time when human powers will stop Biafra

God in heaven come and hear our voice

This protest song appeals to the spiritual in the struggle for Biafra. It declares that human powers cannot stop Biafra and it appeals to heavenly forces. It indicates the primary belief system (both Traditional and Christianity) that attributes all powers to God and constructs God as the ultimate decision maker. As much as the song has a protest orientation, it is also a prayer for God's intervention. The construction of God's support for the Biafra cause propels the interpretations of divine intervention to achieve the Sovereign State of Biafra someday, despite the opposition of the Nigerian state and its use of coercive forces of the State against Biafra agitation. This somewhat explains the so-called adoption of the Judaism by the core figures of Biafra agitation especially among the IPOB members - it is an assumptive expectation of Mosses-like leadership, divine intervention and the destruction of Pharaoh's forces in the Red Sea; in the quest for Biafra.

\section{The Songs of Commitment}

Commitment expresses a dedication to a cause against all the odds. The Biafra protest songs, whether spontaneously created or adapted from an existing collection exalt Igbo commitment to the Biafra cause. The songs encourage every supporter of Biafra to join the protest and be committed to it till death, it presents an alternative identity (to the Nigerian identity) and constructs a symbolic bond of 'we' to show that Biafra is not an individual cause. A song says:

$\begin{array}{ll}\text { Biafra, Biafra } & \text { Biafra, Biafra } \\ \text { Biafra ka m ga eso } & \text { I will follow Biafra } \\ \text { Ma n nga anwu anwu } & \text { Even if I shall die } \\ \text { Ma m nga adi ndu } & \text { Even if I shall live } \\ \text { Biafra ka } m \text { ga eso } & \text { I shall follow Biafra }\end{array}$

This song projects Biafra nationalism. The protesters chant that they are committed to Biafra unto death. It is like a call and chant of patriotism. In this case, the commitment is not to the Nigerian state, but to Biafra. In the hearts and minds of the protesters, Biafra is a 'state', unto whose sovereignty they have sworn and committed their lives to see to fruition. Indeed many activists 
and protesters have been killed in violent encounters with security agencies since the renewed Biafra protests started in the year 2000 (Aghedo, 2017).

Furthermore, it is important to note that Biafra protesters connect the relations of anarchy which may result (and results) in fatalities in the process of protest, with melody to announce and act out the commitment to Biafra, irrespective of fatal consequences. According to Agu (1991), this is typical of nationalist conflict situations. Finally, the protesters sing that Biafra is nonnegotiate. They sing they must have Biafra, and nothing else:

Anyi agagi ekwe ma We will not agree if we

anyi ewegi Biafra

do not have Biafra

Anyi agagi ekwe

We will not agree

Biko si ya ye anyi Biafra

Anyia aga gi ekwe,

Please tell them to give us Biafra

ma anyi ewe gi Biafra

We will not agree if

we do not have Biafra

The connection between the protest and songs reflects the symbolic value attached to Biafra. This protest song demonstrates the act of commitment towards the Biafra cause. The protest song projects the sense of quest and hope and, they emphasise a commitment to the Biafra cause irrespective of challenges that lie ahead. The song appeals to the 'we' consciousness, emphasising the fact that the Biafra struggle is not 'personalised', it is a social struggle advanced by a people bonded together by the values that Biafra represents, irrespective of the attendant violent suppression by the coercive forces of the Nigerian state. In short, the protest songs are the emblems of the Biafra struggle, and they express deep symbolic meanings, which continually internalise Biafra consciousness in the hearts and minds of the convinced population, especially among the Igbo of South-Eastern Nigeria, the rest of Nigeria and in the Diaspora.

\section{Summary and Conclusion}

In summary, Biafra protest has a long history in the Nigerian Civil War and the perceived political marginalisation of the Igbo. Since the return to democratic rule in 1999, there have been several pro-Biafra protests, especially in Southeastern Nigeria. The Biafra protest songs are consciously and unconsciously constructed from the state of activism, and the songs are either cultural or religious songs, are adopted to conjure and promote Biafra sovereignty and advance Igbo cohesive support and commitment to the struggle. The songs emphasise that protesters are in support of Biafra as a value of identity, because of the conviction that Biafra struggle is aimed at social justice and because of individual and group commitment. Hence, the songs were used mitigate the fear of Nigerian Police and military, and to encourage protesters to remain committed, united and hopeful to increase Biafra consciousness and group cohesion during protest. Besides, these protests have been staged alongside the chants of symbolic protest songs to accentuate the deep meanings, values, and commitment to Biafra. Indeed, globally, songs are a 
significant part of the activities of social movement groups during protests, this research, however, submits that the songs are not mere expressions of the aggrieved. Biafra protest songs bear the symbolism of Biafra; it conveys protesters (and by extension Igbo) convictions about Biafra, the constructions of the Biafra self-concept among Igbo actors, and the commitment to achieve Biafra, in the end, irrespective of the legal-rational and coercive resistance by the Nigerian state.

\section{References}

Achebe, C. (2012) There was a country. A personal history of Biafra. USA: Penguin Press.

Achuzia, J.O.G. (1986) Requiem Biafra. Enugu: Fourth Dimension Publishers.

Adekson A.O. (2004) The 'Civil Society' Problematique: Deconstructing civility and Southern Nigeria's Ethnic Radicalization. New York and London: Routledge.

Afeno, O.S. (2014) Killings by the security forces in Nigeria: mapping and trend analysis (2006-2014). IFRA-Nigeria, 37: 1-46.

Agbambu, C. \& Oruya, S. (2015) Onitsha pro-Biafra protests turn bloody. Nigerian Tribune Newspaper. Page 2.

Agbiboa, D.E. (2013) Ethno-religious Conflicts and the Elusive Quest for National Identity in Nigeria. Journal of Black Studies, 44(1): 3-30.

Aghedo, I. (2017) "The Ubiquity of Violent Conflicts in Nigeria." The Round Table: The Commonwealth Journal of International Affairs, 106(1): 97-99, doi.org/10.1080/00358533.2016.1272948.

Agu, O. (1991) Songs and war: The mixed messages of Biafran War songs. African Languages and Cultures, The Literatures of War, 4(1): 5-19.

Akinwumi, O. (2005) Ethinicization of violence, In Saliu, H.A. (ed.) Nigeria under democratic rule, 1990-2003. Ibadan: University Press Plc.

Ashforth, B.E. and Mael, F. (1989) Social identity theory and organization. The Academy of Management Review, 14(1): 20-39.

Brooks, C. (2014) "The Maternal is Political: Appalachian Maternalist Protest Songs" In Kinser, A., Freehling-Burton, K. \& Hawkes, T. (Eds.). Performing Motherhood: Artistic, Activist, and Everyday Enactments, (pp. 34-51). Bradford, ON: Demeter Press.

Bruce, S. and Yearley, S. (2006) The sage dictionary of sociology. London: Sage Publication.

Carter, M.J. and Fuller, C. (2015) Symbolic interactionism, Sociopedia.isa, DoI: $10.1177 / 205684601561$.

Cooke, P. \& Doornbos, M. (1982) Rwenzururu Protest Songs. Journal of the International African Institute, 52(1): 37-60.

Dalton, R., Sickle, A.V. \& Weldon, S. (2010) The individual-institutional nexus of protest behaviour. British Journal of Political Science, 40(1): 5173. 
Diamond, S. (2007) Who killed Biafra? Dialectical Anthropology, 31(1:3): 339-362.

Duruji, M.M. (2009) Social inequity, democratic transition and the Igbo nationalism resurgence in Nigeria. African Journal of Political Science and International Relations, 3(1): 54-65.

Ebeogu, A. (1992) The spirit of agony: War poetry from Biafra. Research in African Literatures, 23(4): 35-49.

Effiong, P. (2000) Nigeria and Biafra: My Story. Aba: Business Forum Publication.

Ezeigbo, T.A. \& Gunner, L. (1991) Foreword. African Languages and Cultures. The Literatures of War, 4(1): 1-4.

Fine, G.A. (1993) The sad demise, mysterious disappearance, and glorious triumph of symbolic interactionism. Annual Review of Sociology, 19: 6187.

Ghanem, H. (2016) The Arab Spring Five Years Later: Toward Great Inclusiveness. Washington, D.C.: Brookings Institution Press.

Gunner, L. (1986) A dying tradition? African oral literature in a contemporary context. Social Dynamics, 12)2): 31-38.

Hawley, J.C. (2008) Biafra as Heritage and Symbol: Adichie, Mbachu and Iweala. Research in African Literatures, 39(2): 15-26.

Ibeanu, O., Orji, N. \& Iwuamadi, C.K. (2016) Biafra separatism, cause, consequences and remedies. Enugu: Institution for Innovation in Development.

Ibekwe, N. (2016) How Nigerian security forces killed 150 pro-Biafra protesters-Amnesty international. Retrieved from www.premiumtimesng.com/news/headlines/216166-nigerian-security-forces-killed-150-probiafra-protesters-amnesty-international.html.

Ihejirika, C. (2015) Pro-Biafra protesters storm Umuahia. Nigerian Tribune Newspaper, Page 43.

McNamara, T. (1997) Theorizing social identity: What Do we mean by social identity? Competing frameworks, competing discourses. TESOL Quarterly, 31(3): 561-567.

Nwachukwu-Agbada, J.O.J. (1996) Lore from friction. Praise and protest in Biafran War Songs. Anthropos, 91(4.-6.): 525-534.

Nzeagwu, U., Ogugbuaja, C., Tsokar, K. and Ilozue, C. (2015) Five killed, 20 injured in pro-Biafra protests. The Guardian, 3 December. https://guardian. ng/news/five-killed-20-injured-in-pro-biafra-protests/.

Obe, E. (2013) Four killed in MASSOB security clash. Punch newspaper, November 12. Retrieved on December 10, 2014 from www.punchng.com/ news/four-killed-in-massob-secruity-clash.

Okonta, I. \& Meagher, K. (2009) Legacies of Biafra: Violence, Identity and Citizenship in Nigeria. Africa Development, 34(1): 1-7.

Okonta, I. (2012) Biafran Ghosts: The MASSOB ethnic militia and Nigeria's democratisation process. UK: The Nordic Africa Institute. 
Omeje, K. (2005) Enyimba Enyi: The Comeback of Igbo Nationalism in Nigeria. Review of African Political Economy, 32: 630-636.

Onuoha, G. (2011) Contesting the space: The new Biafra and ethno-territorial separation in South-Eastern Nigeria. Nationalism and Ethnic Politics, 17(4): 402-422.

Onwuegbuchulam, S.P. and Mtshali, K. (2017) "To Be or Not to Be? A Theoretical Investigation into the Crisis of National Identity in Nigeria". Africa Today, 64(1): 75-97. doi:10.2979/africatoday.64.1.04.

Payerhin, M. (2012) Singing out of pain: Protest songs and social mobilization. The Polish Review, 57(1): 5-31.

Ritzer, G. (2012) Sociological Theory. Eighth edition. New York: McGraw Hill Companies.

Simola, R. (2000) Time and identity: the legacy of Biafra to Igbo in diaspora. Nordic Journal of African Studies, 9(1): 98-117.

Stets, J.E. \& Burke, P.J. (2000) Identity theory and social theory. Social Psychology Quarterly, 63(3): 224-237.

Stets, J.E. \& Burke, P.J. (2003) A sociological approach to self and identity. In Mark Leary and June Tangney. A handbook of self and identity, Washington: Guildford Press.

Ugwuanyi, S. (2016) Army explains why it attacked protesting MASSOB, IPOB members. Retrieved from http://dailypost.ng/2016/05/31/army-explains-why-itattacked-protesting-massob-ipob-members/.

Ujumadu, V. (2013) One killed, 10 injured as police, MASSOB clash in Onitsha. Retrieved January 8, 2015 from http://www.vanguardngr.com/ 2013/12/one-killed-10-injured-police-massob-clash-onitsha/\#sthash.7yMU V0F9.dpuf.

Ukiwo, U. (2009) Violence, identity mobilization and the reimagining of Biafra. Africa Development, 34(1): 9-30.

Uzoaru, S. (2015) MASSOB, Police clash in Owerri. Retrieved August 12, 2016 from http://leadership.ng/news/437207/massob-police-clash-in-owerri.

Van Stekelenburg \& Klandermans, B. (2010) The social psychology of protest. Sociopedia.isa, DOI: 10.1177/205684601076. 